\title{
Analisis Kestabilan Model Predator-Prey dengan Penambahan Makanan Alternatif dan Fungsi Respon Holling Tipe III
}

\author{
Wilda Mahmudah ${ }^{1}$, Mohammad Rifai $^{2}$ \\ ${ }^{1}$ Pendidikan Matematika, Universitas Qomaruddin, Gresik, Indonesia; \\ wilda0403@gmail.com \\ 2Pendidikan Matematika, Universitas Qomaruddin, Gresik, Indonesia; \\ vianditrivai@gmail.com
}

\begin{abstract}
Abstrak. Model predator-prey merupakan model interaksi dan pola perilaku antara dua spesies. Hubungan interaksi tersebut dinyatakan dalam bentuk model sistem dinamik atau persamaan differensial yang bergantung pada waktu. Pada kenyataan di lapangan predator sering mencari mangsa lain ketika jumlah mangsa yang biasa dimakannya menurun, sehingga perlu adanya penambahan makanan alternatif dan juga fungsi respon Holling pada model predator-prey yang ada. Pada penelitian ini, dilakukan analisis kestabilan pada model sistem predator-prey dengan penambahan makanan alternatif dan fungsi respon Holling tipe III. Tujuan dari penelitian ini adalah untuk mengetahui bagaimana kestabilan pada sistem tersebut. Prosedur penelitian ini adalah studi literatur, merekonstruksi pembentukan model predatorprey, menentukan titik kesetimbangan, menentukan kestabilan dititik kesetimbangan, mensimulasikan sistem predator-prey, dan penarikan kesimpulan. Dari hasil analisis didapatkan tiga titik kesetimbangan yaitu kepunahan predator-prey $\left(\mathrm{E}_{0}\right)$, kepunahan predator $\left(\mathrm{E}_{1}\right)$ dan predator-prey saling berinteraksi atau hidup bersama (E2). Pada titik kesetimbangan E0 bersifat tidak stabil, sedangkan pada $E_{1}$ dan $E_{2}$ bersifat stabil asimtotis dengan syarat batas tertentu. Hasil simulasi numerik juga menunjukkan bahwa stabilitas yang ditunjukkan untuk ketiga titik kesetimbangan juga memberikan hasil yang sama dengan hasil analitik.
\end{abstract}

Kata Kunci: Alternatif Makanan; Fungsi Respon Holling Tipe III; Kestabilan; Model Predator-prey;

Abstract.The predator-prey model is a model of interaction and behavior patterns between two species. Such interaction is presented in the form of dynamic systems or differential equations of time. In the field, predators often look for other prey while the prey which they eat is decreasing, so it is necessary to add alternative food and also Holling type III function response in the predator-prey model. In this research, a stability analysis was carried out in the predator-prey system by adding alternative food and also Holling type III function response. The purpose of this research is to 
know the stability of the system. The procedure of this research was literature review, reconstructing the predator-prey model, determining the equilibrium point, determining the stability at the equilibrium point, simulating the solution field and taking phase portraits, and drawing conclusion. The analysis resulted that there were three points of equilibriums, that is, predator-prey extinction $\left(\mathrm{E}_{0}\right)$, predator extinction $\left(E_{1}\right)$ and the interaction of prey and predator or when they are living together $\left(E_{2}\right)$. If $E_{0}$ resulted that the system is unstable, while in $E_{1}$ and $E_{2}$ the system is asymptotically stable with certain boundary conditions. The numerical simulation also resulted that the stability shown by the three equilibrium points also gave the same results as the analytical results.

Keywords: Alternative Food; Holling Type III Functional Response; Stability; Predator-prey Model;

\section{Pendahuluan}

Setiap makhluk hidup membutuhkan interaksi dengan makhluk hidup lainnya untuk kelangsungan hidupnya. Interaksi tersebut mengakibatkan terjadinya ketergantungan antar makhluk hidup apapun perannya, baik sebagai produsen, konsumen, ataupun pengurai. Dalam sistem ekologi, interaksi hubungan antara mangsa dan pemangsa disebut predator-prey, dimana prey merupakan suatu organisme yang dimakan, dan predator adalah organisme yang memakan (Ummah \& Abadi, 2013). Salah satu ciri dari populasi prey adalah lebih cenderung mempunyai stok makanan yang cukup dalam lingkup habitatnya, sedangkan populasi predator sangat bergantung pada jumlah populasi prey. Jika populasi prey menurun, maka populasi predator juga akan mengalami penurunan. Ketika populasi prey tidak ada maka predator tidak akan bisa mempertahankan kelangsungan hidupnya. Begitu pula sebaliknya, predator bertindak sebagai pengendali populasi prey. Proses makan-dimakan tersebut mempengaruhi keseimbangan populasi makhluk hidup di alam. Keseimbangan makhluk hidup dapat tercapai apabila jumlah rata-rata populasi predator-prey sesuai dengan ukuran dan proporsinya (Airlangga, 2016). Secara matematis, interaksi predator-prey dapat digambarkan dalam bentuk persamaan model matematika yang melibatkan suatu variabel dan turunannya (Ismagilova, 2014).

Pada Tahun 1926 model matematika sistem predator-prey pertama kali didefinisikan oleh Lotka-Voltera sebagai laju pertumbuhan makhluk hidup yang tumbuh secara eksponensial (Ismagilova, 2014). Model Lotka-Voltera tersebut adalah sebagai berikut :

$$
f(x, y)=\frac{d x}{d t}=r_{1} x-\alpha y
$$

Copyright (C) 2020

Buana Matematika :

Jurnal Ilmiah Matematika dan Pendidikan Matematika 


$$
g(x, y)=\frac{d x}{d t}=-r_{2} y+\beta y
$$

Model Lotka-Voltera tersebut dianggap kurang realistis karena tidak memperhitungkan keterbatasan sumber-sumber kehidupan. Terbatasnya sumber-sumber seperti ruang, makanan, dan juga adanya kepadatan populasi yang dapat menyebabkan populasi dibatasi oleh suatu daya dukung (carrying capacity) lingkungan. Tahun 1948 model Lotka-Voltera dimodifikasi oleh Leslie-Gower dengan mempertimbangkan aspek keterbatasan daya dukung lingkungan dan tingkat persaingan. Model Leslie-Gower mengasumsikan bahwa kedua populasi tumbuh secara logistik dimana daya dukung predator sebanding dengan kepadatan prey (Mokodompit et al., 2020). Selain itu model tersebut juga mengasumsikan bahwa populasi predator mempunyai hubungan timbal balik dengan kelangkaan pada populasi prey (Sahamony et al., 2016). Karena adanya keterbatasan daya dukung dan tingkat persaingan maka prey mengalami penurunan sehingga perlu adanya penambahan makanan alternatif untuk predator. Selain itu fungsi respon pada model Lotka-Voltera masih sangat sederhana, dan tidak mempertimbangkan waktu yang diperlukan predator dalam mencari dan mengatasi mangsanya. Pada kenyataan di lapangan, interaksi antara prey dan predator sering rumit. Oleh karena itu fungsi respon pada model Lotka-Voltera perlu dimodifikasi dengan menggunakan fungsi respon. Fungsi respon merupakan fungsi kepadatan mangsa dengan banyaknya makanan yang dimangsa predator (Yunita Nur Afifah et al., 2020). Holling memperkenalkan fungsi respon yang menggambarkan tentang laju pemangsaan predator terhadap prey (Armin et al., 2017). Fungsi respon Holling terdiri dari tiga macam, yaitu tipe I, II, dan III. Fungsi respon tipe I terjadi ketika predator memiliki karakteristik pasif, yakni predator lebih suka menunggu mangsanya datang. Fungsi respon tipe II terjadi pada predator dengan karakteristik aktif dalam pencarian mangsa. Fungsi respon tipe III terjadi pada predator yang cenderung mencari populasi mangsa yang lain ketika populasi mangsa yang biasa dimakan mulai berkurang (Amil Siddik, A.M; Toaha, 2011).

Hubungan dinamis antara prey dan predator merupakan salah satu topik yang sering dikaji peneliti. Banyak penelitian yang telah dilakukan terhadap sistem prey predator. Diantaranya adalah penelitian tentang analisis kestabilan model matematika mangsa pemangsa dua spesies dengan fungsi respon holling tipe II dan perilaku anti pemangsa (Ekawaniningrum 2019), kontrol optimum dari sistem predator-prey dengan pemberian makanan alternatif bagi predator dan adanya usaha pemanenan(Rifai, 2018). Kemudian, penelitian tentang kestabilan model eko-epidemiologi dengan pemanenan konstan pada predator Copyright $\odot 2020$

\section{Buana Matematika :}

Jurnal Ilmiah Matematika dan Pendidikan Matematika 
(Hasan et al., 2019), kendali optimal pada sistem prey predator dengan pemberian makanan alternative pada predator (Resmi, 2019), kestabilan model mangsa pemangsa dengan bentuk Leslie_Gower struktur pada mangsa (Natsir, 2018). Hasil penelitian-penelitian tersebut, menunjukkan bahwa model sistem predator-prey sangat menarik untuk diteliti demi pengembangan keilmuan matematika, khususnya matematika ekologi. Perilaku dinamis predator-prey dapat dilihat dari kestabilan sistemnya.

Dalam perkembangannya, model sistem predator-prey terus mengalami modifikasi demi menggambarkan kondisi yang sebenarnya. Seperti, jika tingkat pertumbuhan populasi prey rendah saat populasi predator meningkat, maka ada kecenderungan predator mencari mangsa yang lain (Didi 2018). Dengan kata lain, predator membutuhkan makanan tambahan sebagai alternatif pengganti prey utama (Mokodompit et al., 2020). Atau supaya model sistem predator-prey lebih realistis maka perlu adanya penambahan fungsi respon Holling pada model..

Berdasarkan uraian tersebut, maka tujuan dari penelitian ini adalah untuk menganalisis kestabilan serta mensimulasikan pola perilaku dari sistem predator-prey dengan adanya penambahan makanan alternatif pada predator dan adanya fungsi respon holling III. Analisis kestabilan yang dimaksud adalah mengetahui kestabilan dari berbagai titik kesetimbangan. Penelitian ini diharapkan dapat menambah pengetahuan dan referensi utamanya dalam bidang matematika ekologi, serta dapat pula menjadi informasi pada penelitian lanjutan yang serupa.

\section{Metode}

Penelitian ini adalah penelitian deskriptif kuantitatif tentang aplikasi matematika pada bidang ekologi dan sumber daya alam. Adapun prosedur penelitian yang digunakan adalah sebagai berikut :

1. Studi Literatur :

Pada tahap ini dilakukan pengkajian dari beberapa buku, jurnal, dan penelitian sebelumnya mengenai model predator-prey.

2. Merekonstruksi bentuk model

Pada tahap ini dilakukan rekonstruksi bentuk model predator-prey dengan penambahan makanan alternatif dan fungsi respon Holling tipe III.

3. Menentukan Titik Setimbang atau titik tetap

Copyright $@ 2020$

Buana Matematika :

Jurnal Ilmiah Matematika dan Pendidikan Matematika 
Menentukan semua titik kesetimbangan dari model sistem predator-prey dengan penambahan makanan alternatif dan fungsi respon Holling tipe III. Syarat yang harus dipenuhi dalam menentukan titik setimbang adalah $f(x, y)=\frac{d x}{d t}=0$ dan $g(x, y)=\frac{d y}{d t}=0$. Pada penelitian ini ada tiga macam titik kesetimbangan yang ditentukan yaitu titik kesetimbangan saat ketiadaan populasi predator-prey, titik kesetimbangan saat kepunahan predator, dan titik kesetimbangan saat predator-prey saling berinteraksi atau hidup saling berdampingan.

4. Menganalisis kestabilan sistem di titik kesetimbangan

Pada tahap ini dilakukan analisis kestabilan dari sistem predator-prey di titik kesetimbangan. Jenis kestabilan dari titik kesetimbangan dapat diketahui dari nilai-nilai eigen persamaan karakteristiknya atau berdasarkan pada kriteria Routh-Hurwitz. (Soleh \& Kholipah, 2013). Oleh karena itu, terlebih dahulu dicari persamaan karakteristik dan nilai eigen dari matriks Jacobian. Sistem dikatakan stabil asimtotis, apabila nilai eigen bagian real-nya bernilai negatif.

\section{Simulasi}

Tahap ini dilkukan simulasi dengan menggunakn Geogebra

6. Menarik kesimpulan

Pada tahap ini dilakukan penarikan kesimpulan.

\section{Hasil dan Pembahasan}

Model Prey Predator dengan penambahan makanan alternative dan fungsi respon Holling tipe III

Model sistem prey predator dengan adanya penambahan makanan alternatif bagi predator dan penambahan fungsi respon holling tipe III yang digunakan dalam penelitian ini adalah sebagai berikut :

$$
\begin{aligned}
& f(x, y)=\frac{d x}{d t}=r_{1} x\left(1-\frac{x}{k}\right)-\frac{\alpha y A x^{2}}{1+x^{2}} \\
& g(x, y)=\frac{d y}{d t}=-r_{2} y+\frac{\alpha \beta y A x^{2}}{1+x^{2}}+(1-A) y
\end{aligned}
$$

dengan $x=x(t)$ adalah banyaknya populasi prey tiap satuan waktu, $y=y(t)$ adalah banyaknya populasi predator tiap satuan waktu, dan $\mathrm{k}, r_{1}, r_{2}, \alpha, \beta$ adalah parameter-parameter yang bernilai positif, dimana parameter $r_{1}$ adalah laju pertumbuhan maksimum dari populasi prey, $r_{2}$ adalah laju kematian relatif

Copyright (c) 2020

\section{Buana Matematika :}

Jurnal Ilmiah Matematika dan Pendidikan Matematika 
predator saat ketiadaan prey, $\mathrm{k}$ menyatakan daya dukung lingkungan, $\alpha$ merupakan laju pemangsaan prey oleh predator, dan $\beta$ adalah laju konversi biomassa prey ke biomassa predator sedangkan A adalah suatu konstanta yang menyatakan proporsi pemberian makanan alternatif bagi predator.

Persamaan (3) adalah model laju pertumbuhan populasi prey yang dipengaruhi oleh laju pertumbuhan alami $r_{1}$ dan menurun karena adanya persaingan antar sesama prey, keterbatasan daya tampung $\mathrm{k}$ serta adanya pemangsaan dari predator. Sedangkan persamaan (4) disebut model laju pertumbuhan populasi predator yang dipengaruhi oleh laju pemangsaan predator terhadap prey dan penambahan makanan alternatif serta berkurang dengan adanya kematian prey. Daerah penyelesaian pada bidang ekologi terutama yang berhubungan dengan pertumbuhan selalu terletak pada kuadran positif yaitu $\mathrm{R}^{2}+$ dimana $r_{2}>1-\mathrm{A}$.

\section{Titik Kesetimbangan}

Titik kesetimbangan diperoleh dari kondisi $\frac{d x}{d t}=\frac{d y}{d t}=0$ pada persamaan (3) dan (4) sehingga diperoleh titik kesetimbangan sebagai berikut :

1. Titik kesetimbangan saat ketiadaan populasi predator-prey

Titik kesetimbangan saat ketiadaan predator-prey adalah $\mathrm{E}_{0}\left(\mathrm{x}_{0}, \mathrm{y}_{0}\right)=\mathrm{E}_{0}(0,0)$

2. Titik kesetimbangan saat kepunahan predator

Titik kesetimbangan saat kepunahan predator adalah $\mathrm{E}_{1}\left(\mathrm{x}_{1}, 0\right)=\mathrm{E}_{1}(\mathrm{k}, 0)$

3. Titik kesetimbangan saat predator-prey saling berinteraksi atau saling berdampingan ( terdapat populasi prey dan predator sehingga saling berinteraksi)

Titik kesetimbangan saat predator-prey saling berinteraksi atau saling berdampingan adalah $\mathrm{E}_{2}\left(\mathrm{x}_{2}, \mathrm{y}_{2}\right)=\mathrm{E}_{2}\left(\sqrt{p}, \frac{r_{1}\left(1-\frac{\sqrt{p}}{k}\right)(1+p)}{\alpha A \sqrt{p}}\right)$ dengan $p=\frac{r_{2}-1+A}{\alpha \beta A-r_{2}+1-A}$

\section{Analisis kestabilan Sistem di Titik Kesetimbangan}

Untuk mendapatkan kestabilan dari masing - masing titik kesetimbangan maka terlebih dahulu dilakukan pelinieran. Kestabilan sistem pada setiap titik kesetimbangan ditentukan dengan mencari nilai eigen atau akar - akar dari persaman karakteristik.

Matriks Jacobian pada sistem prey predator persamaaan (3) dan (4) adalah sebagai berikut : 


$$
\begin{gathered}
J=\left(\begin{array}{ll}
\frac{\partial f}{\partial x} & \frac{\partial f}{\partial y} \\
\frac{\partial g}{\partial x} & \frac{\partial g}{\partial y}
\end{array}\right) \\
\left.J=\left(\begin{array}{cc}
r_{1}-\frac{2 r_{1} x}{k}-\frac{2 \alpha y A x}{\left(1+x^{2}\right)^{2}} & -\frac{\alpha A x^{2}}{1+x^{2}} \\
\frac{2 \alpha \beta y A x}{\left(1+x^{2}\right)^{2}} & -r_{2}+\frac{\alpha \beta A x^{2}}{1+x^{2}}+(1-A)
\end{array}\right)\right)
\end{gathered}
$$

Dengan menggunakan Matriks jacobian tersebut, maka dilakukan analisis kestabilan sistem dengan mendapatkan nilai karakteristik dari determinan matriks jacobian tersebut, sehingga diperoleh :

1. Kestabilan di titik setimbang kepunahan predator-prey $\left(\mathrm{E}_{0}\right)$

Matriks jacobian model (3) dan (4) pada Eo $(0,0)$ adalah :

$$
J(E 0)=\left(\begin{array}{cc}
r_{1} & 0 \\
0 & -r_{2}+(1-A)
\end{array}\right)
$$

Berdasarkan matriks jacobian maka diperoleh persamaaan karakteristik di titik kesetimbangan $E_{0}$ sebagai berikut :

$$
\begin{gathered}
\operatorname{det}\left(\begin{array}{cc}
r_{1}-\lambda & 0 \\
0 & -r_{2}+(1-A)-\lambda
\end{array}\right)=0 \\
\left(r_{1}-\lambda\right)\left(-r_{2}+(1-A)-\lambda\right)=0
\end{gathered}
$$

Sehingga diperoleh nilai eigen :

$$
\lambda_{1}=r_{1} \text { atau } \lambda_{2}=-r_{2}+(1-A)
$$

Karena $r_{1}$ merupakan parameter yang selalu bernilai positif maka $\lambda_{1}$ selalu bernilai positif, sedangkan $\lambda_{2}$ akan selalu bernilai negatif karena $r_{2}>(1-\mathrm{A})$. Oleh karena itu titik kesetimbangan Eo bersifat tidak stabil (saddle). Hal ini memberikan arti bahwa dalam kurun waktu yang lama tidak akan ada populasi prey yang bertahan hidup sehingga populasi predator akan punah.

2. Kestabilan di titik setimbang kepunahan predator $\left(\mathrm{E}_{1}\right)$

Matriks jacobian model (3) dan (4) pada E1 $(\mathrm{k}, 0)$ adalah

$$
J(E 1)=\left(\begin{array}{cc}
-r_{1} & \frac{-\alpha A k^{2}}{1+k^{2}} \\
0 & -r_{2}+\frac{\alpha \beta A k^{2}}{1+k^{2}}+(1-A)
\end{array}\right)
$$

Berdasarkan matriks jacobian tersebut maka diperoleh persamaaan karakteristik di titik kesetimbangan kepunahan predator sebagai berikut:

Copyright (C) 2020

\section{Buana Matematika :}

Jurnal Ilmiah Matematika dan Pendidikan Matematika 


$$
\begin{gathered}
\operatorname{det}\left(\begin{array}{cc}
-r_{1}-\lambda & \frac{-\alpha A k^{2}}{1+k^{2}} \\
0 & -r_{2}+\frac{\alpha \beta A k^{2}}{1+k^{2}}+(1-A)-\lambda
\end{array}\right)=0 \\
\left(-r_{1}-\lambda\right)\left(-r_{2}+\frac{\alpha \beta A k^{2}}{1+k^{2}}+(1-A)-\lambda\right)=0
\end{gathered}
$$

Sehingga diperoleh nilai eigen :

$$
\lambda_{1}=-r_{1} \text { atau } \lambda_{2}=-r_{2}+\frac{\alpha \beta A k^{2}}{1+k^{2}}+(1-A)
$$

Karena $r_{1} \geq 0$ maka $\lambda_{1}$ selalu bernilai negatif, dan $\lambda_{2}$ akan bernilai negatif untuk $r_{2}>\frac{\alpha \beta A k^{2}}{1+k^{2}}+(1-A)$ maka pada kondisi ini sistem akan stabil asimtotis jika memenuhi $r_{2}>\frac{\alpha \beta A k^{2}}{1+k^{2}}+(1-A)$. Sedangkan untuk $r_{2}<\frac{\alpha \beta A k^{2}}{1+k^{2}}+(1-A)$ pada titik kesetimbangan ini bersifat tidak stabil. Pada kondisi ini pertumbuhan prey mencapai pertumbuhan maksimum sedangkan predator mengalami kepunahan.

3. Kestabilan di titik setimbang prey predator saling berinteraksi atau hidup bersama $\left(\mathrm{E}_{2}\right)$

Matriks jacobian model (3) dan (4) pada $\mathrm{E}_{2}\left(\mathrm{x}_{2}, \mathrm{y}_{2}\right)$ adalah

$$
J(E 2)=\left(\begin{array}{cc}
r_{1}-\frac{2 r_{1} x_{2}}{k}-\frac{2 \alpha y_{2} A x_{2}}{\left(1+x_{2}{ }^{2}\right)^{2}} & \frac{-\alpha A x_{2}{ }^{2}}{1+x_{2}{ }^{2}} \\
\frac{2 \alpha \beta y_{2} A x_{2}}{\left(1+x_{2}{ }^{2}\right)^{2}} & -r_{2}+\frac{\alpha \beta A x_{2}{ }^{2}}{1+x_{2}{ }^{2}}+(1-A)
\end{array}\right)
$$

Berdasarkan matriks jacobian maka diperoleh persamaaan karakteristik di titik setimbang prey predator saling berinteraksi atau hidup bersama sebagai berikut :

$$
\begin{gathered}
\operatorname{det}\left(\begin{array}{cc}
r_{1}-\frac{2 r_{1} x_{2}}{k}-\frac{2 \alpha y_{2} A x_{2}}{\left(1+x_{2}{ }^{2}\right)^{2}}-\lambda & \frac{-\alpha A x_{2}{ }^{2}}{1+x_{2}{ }^{2}} \\
\frac{2 \alpha \beta y_{2} A x_{2}}{\left(1+x^{2}\right)^{2}} & -r_{2}+\frac{\alpha \beta A x_{2}{ }^{2}}{1+x^{2}}+(1-A)-\lambda
\end{array}\right)=0 \\
\left(r_{1}-\frac{2 r_{1} x_{2}}{k}-\frac{2 \alpha y_{2} A x_{2}}{\left(1+x_{2}{ }^{2}\right)^{2}}-\lambda\right)\left(-r_{2}+\frac{\alpha \beta A x_{2}{ }^{2}}{1+x^{2}}+(1-A)-\lambda\right)-\left(\frac{-\alpha A x_{2}{ }^{2}}{1+x_{2}{ }^{2}} \frac{-\alpha A x^{2}}{1+x^{2}}\right)\left(\frac{2 \alpha \beta y_{2} A x_{2}}{\left(1+x^{2}\right)^{2}}\right)=0
\end{gathered}
$$

Sehingga diperoleh persamaan karakteristiknya

$$
a_{0} \lambda^{2}+a_{1} \lambda+a_{2}=0
$$

Copyright (c) 2020

\section{Buana Matematika :}

Jurnal Ilmiah Matematika dan Pendidikan Matematika 


$$
\begin{aligned}
& \begin{array}{l}
\text { dengan } \\
a_{0}=1
\end{array} \\
& a_{1}=-r_{1}+\frac{2 r_{1} x_{2}}{k}+\frac{2 \alpha A x_{2} y_{2}}{\left(1+x^{2}\right)^{2}}-\frac{\alpha \beta A x_{2}{ }^{2}}{\left(1+x^{2}\right)^{2}}+r_{2}-(1-A) \\
& a_{2}=-r_{1} r_{2}+r_{1}(1-A)-\frac{2 \alpha \beta A r_{1} x_{2}^{3}}{k\left(1+x_{2}^{2}\right)}-\left(\frac{2 r_{1} r_{1} x_{2}-2 r_{1} x_{2}(1-A)}{k}\right) \\
& \quad+\left(\frac{\alpha \beta A r_{1} x_{2}^{2}-2 r_{1} x_{2}(1-A)}{1+x_{2}^{2}}\right)+\left(\frac{2 \alpha A x_{2} y_{2}(r-(1-A))}{\left(1+x_{2}\right)^{2}}\right)
\end{aligned}
$$

Kestabilan pada kasus ini diperoleh melalui kriteria kestabilan RouthHurwitz. Menurut aturan Routh - Hurwitz nilai eigen dari persamaan sehingga pada titik kesetimbangan E2 dikatakan stabil jika $a_{1}>0$ dan $a_{2}>0$. Oleh karena itu pada titik ini terjadi kestabilan asimtotik.

Simulasi dilakukan untuk melihat kesesuaian antara hasil analisis dengan numeriknya. Simulasi dilakukan dengan menggunakan Geogebra. Adapun parameter yang digunakan adalah $\mathrm{r}_{1}=0.6 ; \alpha=0.4 ; \beta=0.2 ; \mathrm{A}=0.6$. Simulasi dilakukan pada beberapa titik kesetimbangan.

Gambar 1 menunjukkan hasil simulasi dengan $\mathrm{k}=10$, dan $\mathrm{r}_{2}=0,6$ dengan kata lain memenuhi $r_{2}>\frac{\alpha \beta A k^{2}}{1+k^{2}}+(1-A)$. pada Gambar 1 terlihat ada dua titik kesetimbangan yaitu $\mathrm{E}_{0}(0,0)$ dan $\mathrm{E}_{1}\left(\mathrm{k}_{,}, 0\right)=\mathrm{E}_{1}(10,0)$. Semua panah terlihat menjauhi titik $0(0,0)$, sehingga dikatakan bahwa titik kesetimbangan $\mathrm{E}_{0}(0,0)$ bersifat tidak stabil (saddle) sedangkan pada $\mathrm{E}_{1}(10,0)$ terlihat bahwa semua panah mengarah ke titik $(10,0)$ sehingga dikatakan bahwa $E_{1}(10,0)$ bersifat stabil asismtotis. Hal ini sesuai dengan hasil analisis bahwa titik E1 akan stabil ketika memenuhi kondidi $r_{2}>\frac{\alpha \beta A k^{2}}{1+k^{2}}+(1-A)$. Jadi pada titik $\mathrm{E}_{1}$ terjadi kestabilan jumlah predator dan prey. 


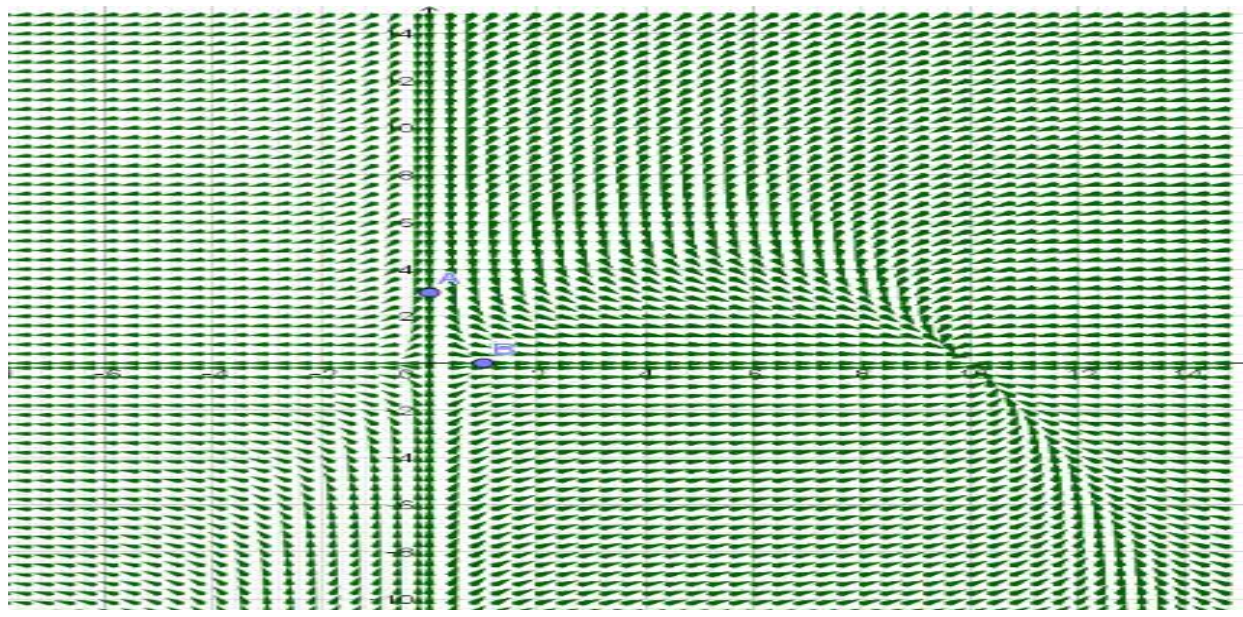

Gambar 1. Trayektori di $\mathrm{E}_{0}$ bersifat tidak stabil dan E1 bersifat stabil asimtotis

Gambar 2 menunjukkan hasil simulasi dengan $\mathrm{r}_{2}=0.42$ dan $\mathrm{k}=10$, adapun nilai $\mathrm{k}$ yang digunakan disini merujuk pada penelitian Sahamony dkk (Sahamony et al., 2016)). Pada Gambar 2 terlihat bahwa semua panah mengarah ke titik $(0.84,5.2)$, hal ini berarti pada titik kesetimbangan $\left(\mathrm{x}_{2}, \mathrm{y}_{2}\right)=$ $(0.84,5.2)$ bersifat stabil. Ketika $\mathrm{r}_{2}=0.42$ memenuhi kondisi $a_{1}>0$ dan $a_{2}>0$. Hal ini sesuai dengan hasil analisis diawal yang menyatakan bahwa sistem akan stabil pada kesetimbangan $E_{2}$ dengan syarat $a_{1}>0$ dan $a_{2}>0$. Begitu juga dengan simulasi pada titik kesetimbangnlainnya. Beberapa simulasi yang dilakukan juga menunjukkan bahwa ada kesesuaian antara hasil analitik dengan hasil simulasi numerik. Selain itu dari simulasi juga terlihat bahwa jika A semakin besar maka system akan semakin cepat stabil menuju titik kesetimbangan, hal ini sesuai dengan penelitian Safiti yang menyatakan bahwa semakin besar makanan tambahan yang diberikan kepada pemangsa Sistem akan semakin cepat stabil menuju titik tetap. (Safitri \& Mardlijah, 2019).

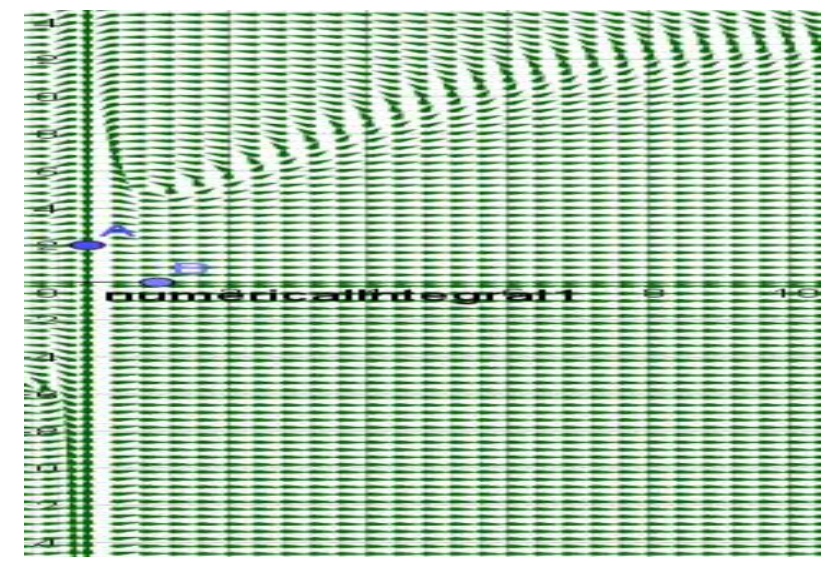

Gambar 2. Trayektori E2 yang stabil

Copyright (C) 2020

Buana Matematika:

Jurnal Ilmiah Matematika dan Pendidikan Matematika 


\section{Simpulan}

Berdasar pembahasan diatas diperoleh bahwa :

1. Model Predator-Prey dengan penambahan makanan alternatif dan fungsi respon holling tipe III adalah sebagai berikut :

$$
\begin{gathered}
f(x, y)=\frac{d x}{d t}=r_{1} x\left(1-\frac{x}{k}\right)-\frac{\alpha y A x^{2}}{1+x^{2}} \\
g(x, y)=\frac{d y}{d t}=-r_{2} y+\frac{\alpha \beta y A x^{2}}{1+x^{2}}+(1-A) y
\end{gathered}
$$

2. Berdasar hasil analisis diperoleh tiga titik kesetimbangan dan sifat kestabilannya yaitu :

a. $E_{0}(0,0)$ yang bersifat tidak stabil, yang berarti bahwa dalam kurun waktu yang cukup lama tidak ada populasi prey yang bertahan hidup sehinga populsi predator juga akan punah.

b. $\mathrm{E}_{1}(\mathrm{k}, 0)$ yang bersifat stabil asimtotis dengan syarat memenuhi syarat $r_{2}>\frac{\alpha \beta A k^{2}}{1+k^{2}}+(1-A)$. Hal ini berarti bahwa jika syarat batas tersebut terpenuhi maka untuk waktu yang lama prey dapat bertahan hidup sehingga populasi predator juga akan bertahan hidup.

c. $\mathrm{E}_{2}\left(\mathrm{x}_{2}, \mathrm{y}_{2}\right)$ yang bersifat stabil asimtotis dengan syarat $a_{1}>0, a_{2}>0$. Hal ini berarti bahwa jika syarat batas tersebut terpenuhi maka untuk waktu yang lama prey dapat bertahan hidup sehingga populasi predator juga akan bertahan hidup sesuai dengan proporsi mangsanya.

d. Hasil simulasi menunjukkan hasil yang sama dengan hasil analisis.

\section{Daftar Pustaka}

39-Article Text-60-1-10-20180817 (2).pdf. (n.d.).

Airlangga, P. U. (2016). Apln - perpustakaan universitas airlangga. Cd, 6-25.

Amil Siddik, A.M ; Toaha, s; kasbawati et all. (2011). Kestabilan Model Mangsa Pemangsa. 8(2), 23-32.

Armin, Toaha, S., \& Kasbawati. (2017). ANALISIS KESTABILAN PADA MODEL DUA MANGSA- SATU PEMANGSA DENGAN FUNGSI RESPON HOLLING DAN PEMANENAN. Matematika Dan Aplikasinya. EKAWATI NINGRUM, R. (2019). Model Matematika Mangsa Pemangsa Dua Spesies Dengan Fungsi Respon Holling Tipe Ii Dan Perilaku AntiPemangsa. MATHunesa, 7(2), 114-121.

Hasan, N., Resmawan, R., \& Rahmi, E. (2019). Analisis Kestabilan Model EkoEpidemiologi dengan Pemanenan Konstan pada Predator. Jurnal Matematika, Statistika Dan Komputasi, 16(2), 121. https://doi.org/10.20956/jmsk.v16i2.7317

Copyright (c) 2020

\section{Buana Matematika :}

Jurnal Ilmiah Matematika dan Pendidikan Matematika 
Ismagilova, G. (2014). No 主観的健康感を中心とした在宅高齡者における健康 関連指標に関する共分散構造分析Title.11(c), 363-367.

Mokodompit, R., Nurwan, N., \& Rahmi, E. (2020). Bifurkasi Periode Ganda dan Neimark-Sacker pada Model Diskret Leslie-Gower dengan Fungsi Respon Ratio-Dependent. Limits: Journal of Mathematics and Its Applications. https://doi.org/10.12962/limits.v17i1.6809

Natsir, N. (2018). Kestabilan Model Mangsa Pemangsa dengan Bentuk Leslie-Gower Struktur pada Mangsa. 5(2), 17-26.

Resmi, F. (2019). Kendali Optimal pada Sistem Prey Predator dengan Pemberian Makanan Alternatif pada Predator. JURNAL MATHEMATIC PAEDAGOGIC. https://doi.org/10.36294/jmp.v4i1.762

Safitri, O., \& Mardlijah, M. (2019). Kontrol Optimum pada Model Predator-prey dengan Pemanenan pada Ikan Prey dan Ikan Predator. Limits: Journal of Mathematics and Its Applications. https://doi.org/10.12962/limits.v16i1.4607

SAHAMONY, N. F., SIANTURI, P., \& JAHARUDDIN, J. (2016). ANALISIS BIFURKASI MODEL LESLIE GOWER TIPE HOLLING II DENGAN WAKTU TUNDA. Journal of Mathematics and Its Applications. https://doi.org/10.29244/jmap.15.1.33-44

Soleh, M., \& Kholipah, S. (2013). Model Matematika Mangsa-Pemangsa Dengan Sebagian Mangsa Sakit. Jurnal Sains, Teknologi Dan Industri, 10(2), 59-63.

Ummah, C., \& Abadi. (2013). Analisis Kestabilan Model Ekoepidemiologi Dengan Pemanenan Sebagai Kontrol Penyebaran Penyakit. MATHunesa.

Yunita Nur Afifah, MNH Qomarudin, \& Imamatul Ummah. (2020). Optimal Control Model Pemanenan Predator-prey di Area Konservasi Ikan. Buana Matematika: Jurnal Ilmiah Matematika Dan Pendidikan Matematika, 10(1), 116. https://doi.org/10.36456/buanamatematika.v10i1.2410

\section{Riwayat Hidup Penulis}

\section{Wilda Mahmudah}

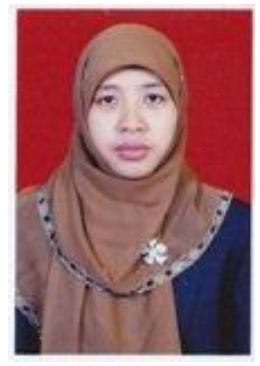

Lahir di Gresik, 04 Maret 1984. Dosen di Universitas Qomaruddin. Studi S1 Matematika ITS Surabaya, Lulus Tahun 2006; S2 Matematika ITS Surabaya, Lulus tahun 2009.

Copyright (C) 2020

Buana Matematika :

Jurnal Ilmiah Matematika dan Pendidikan Matematika 


\section{Mohammad Rifai}

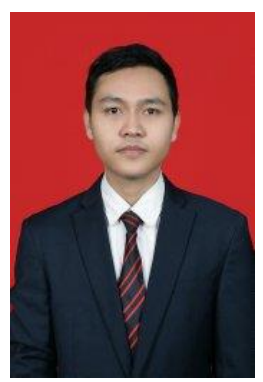

Lahir di Gresik, 10 Maret 1989. Dosen di Universitas Qomaruddin. Studi S1 Matematika ITS Surabaya, Lulus Tahun 2012; S2 Matematika ITS Surabaya, Lulus tahun 2014. 
Jurnal Ilmiah Matematika dan Pendidikan Matematika Vol. 10 No. 2 (2020)

Copyright (C) 2020

Buana Matematika :

Jurnal Ilmiah Matematika dan Pendidikan Matematika 